\title{
Dois temas clássicos em Virgílio e no canto VI d’Os Lusíadas de Camões
}

\author{
Matheus Trevizam*
}

\begin{abstract}
RESUMO
Neste artigo, intentamos demonstrar como se dá a incorporação de dois temas clássicos ao sexto canto d'Os Lusíadas, de Luís de Camões (1572). Isso ocorre, no canto mencionado, ao longo das estâncias 7-37, nas quais se desenvolve o assunto da viagem a um reino (divino) sob as águas e, depois, do concílio dos deuses (marinhos). Tais desenvolvimentos camonianos encontram possíveis "antecessores", segundo intentaremos demonstrar, no quarto livro das Geórgicas de Virgílio - visita de Aristeu à ninfa Cirene (v. 317-418) - e no décimo canto (v. 1-117) da Eneida do mesmo poeta romano. Desse modo, a leitura cotejada de Camões e Virgílio nos passos citados oferece-nos meios concretos de divisarmos a "tradição clássica" em operação na obra desse autor renascentista português.
\end{abstract}

Palavras-chave: Tradição clássica. Os Lusíadas. Virgílio. Viagem subaquática. Concílio divino.

\section{A poesia épica clássica greco-romana e sua "transposição" para a cultura portu- guesa dos Quinhentos}

Para o leitor de língua portuguesa, revisitar Os Lusíadas, épico maior do idioma, significa continuamente deparar elementos e assuntos oriundos de sólida matriz clássica. Por "clássica", nesse caso, entendemos aqueles fatores constitutivos do poema camoniano que não se inserem, propriamente, no legado judaico-cristão, mas sim nas realizações espirituais dos romanos e helenos da Antiguidade: ${ }^{1}$ por sinal, o próprio gênero épico, tal como manifesto durante o Renascimento português na obra literária aqui tomada para objeto de estudo, já

\footnotetext{
1 Sobre a mistura entre aspectos judaico-cristãos e do paganismo na feitura d'Os Lusíadas, Moisés afirma: "Eis porque se apresenta marcada de contradições e dualidades, como, por exemplo, a coexistência do 'maravilhoso' (= intervenção de deuses sobrenaturais no poema) pagão e do cristão, quando seria de esperar que o segundo predominasse. Tal dualismo, como sabemos, é francamente renascentista." (MOISÉS, 2005, p. 59 - destaques do autor).

" Faculdade de Letras da Universidade Federal de Minas Gerais. Agradeço ao prof. Dr. Teodoro Rennó Assunção (FALE-UFMG) pela leitura e proveitosas sugestões ao resumo em língua francesa.
} 
inscreve a mesma iniciativa de Camões naquele Universo longínquo no tempo, mas jamais de todo olvidado em sua natureza de uma das principais bases para o estabelecimento da cultura Ocidental. ${ }^{2}$

Assim, elementos poéticos do tipo da celebração heroica, individual ou coletiva, do emprego da mitologia, da narrativa dos temas da viagem e da guerra, com todos os seus desencontros e perigos, da eventual homenagem a um soberano

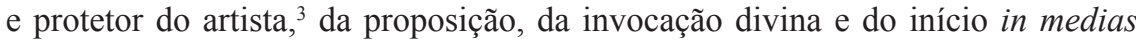
res perpassam a tradição compositiva dos textos do gênero, por vezes, desde os clássicos homéricos da Ilíada e da Odisseia. ${ }^{4}$ Ainda, tendo-se Roma Antiga constituído, desde, pelo menos, o século III a.C., em legítima "herdeira" do legado cultural heleno, ${ }^{5}$ tais modos literários também se incorporaram às produções épicas dos latinos, os quais souberam, sobretudo a partir de Ênio, enriquecer os meios expressivos pátrios com as célebres realizações daqueles a quem dominaram, apenas, pelas armas. ${ }^{6}$

Lembremos, aqui, a propósito do estabelecimento da tradição clássica como uma espécie de chama criadora passada de tempos em tempos de um a outro povo, depois da "centelha" grega original, que a própria literatura romana se iniciou com uma obra tradutória de Lívio Andronico, o qual, em meados do século III a.C., compôs uma Odissia em latim, nos versos saturnianos característicos da poética

2 Não só na literatura a influência dos gregos e romanos persistiu, por séculos, como uma das mais presentes nas culturas de matriz europeia (até nas colônias da América). Os testemunhos de Arnold Hauser, em seu clássico estudo a respeito da história social da arte, assim, atestam a importância de Vitrúvio, arquiteto romano dos tempos do imperador Otaviano Augusto, para o estabelecimento das doutrinas atinentes a esse saber, por exemplo, em Leon Battisti Alberti (1404-1472), importante teórico e construtor do Renascimento italiano (HAUSER, 2003, p. 359).

$3 \mathrm{Na}$ Eneida, as homenagens ao soberano então reinante, Otaviano Augusto, principiam pela escolha de Eneias para protagonizar a trama, pois seu filho, Iulo, era reputado fundador mítico da gens Júlia, a que pertencia o imperador... Camões, porém, em sua época louva e dedica a obra ao rei Dom Sebastião, como se pode ler a partir da sexta estância do canto I d'Os Lusíadas.

4 A Ilíada concentra-se, é sabido, em um episódio da Guerra de Troia, vale dizer, a chamada "ira de Aquiles", depois de o rei Agamêmnon ter privado esse altivo herói de Briseida, a qual lhe coubera como parte de seu butim bélico; na Odisseia, por sua vez, o leitor encontra o relato arquetípico do nóstos, ou "retorno", de Ulisses para a ilha natal de Ítaca, depois de anos em guerra e de andanças aventurescas pelo mar.

5 Nesse período, coincidente com a decisiva expansão romana no Mediterrâneo, por motivos ligados ao evento das "Guerras Púnicas" contra Cartago, Roma passou a ser, como nunca antes em sua história, maciçamente exposta a tendências culturais estrangeiras, que lhe chegavam, sobretudo, do Oriente helenizado. Essa influência, no âmbito literário, mostra-se na cultura latina desde algumas de suas mais precoces realizações, caso da obra perdida de Andronico, das comédias plautinas e, mesmo, do De agricultura de Catão Censor. (GRIMAL, 1994, p. 85 et seq.).

6 Cf. HORÁCIO, Epístolas II, I, 156: Graecia capta ferum uictorem cepit et artes intulit agresti Latio - "A Grécia capturada ao feroz vencedor capturou e trouxe as artes ao agreste Lácio." 
itálica. Tratou-se, provavelmente, de um trabalho rude e em princípio destinado apenas a fins escolares de educação literária de meninos $;{ }^{7}$ contudo, esta iniciativa letrada, vale destacar, parece ter dado curso a práticas, em seguida, correntes e de todo indispensáveis para estabelecer as letras de Roma como uma amálgama constante de componentes estrangeiros e locais. ${ }^{8}$

Na sequência cronológica, Ênio tornou-se o primeiro adaptador da métrica grega no contexto da épica romana, tendo escrito seus Annales nos mesmos versos hexâmetros datílicos de Homero (GRIMAL, 1994, p. 104): estes eram, do ponto de vista temático, uma obra de ambientação latina, pois os preenchiam assuntos da história de Roma expostos em andamento anual, na maneira aproximada dos velhos "Anais pontificais". 9 Coube, porém, a Virgílio, autor da Eneida, apropriar-se do legado épico homérico com plena maturidade, tanto porque ele o fez com inegável apuro quanto pelo fato de ter extraído, conscientemente, sofisticados efeitos do diálogo crítico com a tradição herdada.

Assim, já há muito se tem como um dado admissível a partir da leitura da Eneida que o poeta fundiu em seu único texto épico a Ilíada e a Odisseia de Homero, correspondendo a Odisseia virgiliana à primeira metade da obra, com o tema predominante da viagem de Eneias e os demais remanescentes do povo de Troia até a Itália, onde haveriam de fundir-se com os locais para lançar as bases do estabelecimento da Urbe (VASCONCELLOS, 2001, p. 189 et seq.); os cantos inseridos do meio para o fim da mesma obra, por sua vez, acabam por corresponder a uma Ilíada, com desdobramentos sobretudo atinentes às cruezas e heroísmos da guerra entre os partidários do forasteiro Eneias e os aliados do rútulo Turno. (VASCONCELLOS, 2001, p. 287 et seq.).

Ademais, Virgílio também se apropria nas tramas de sua obra dos elementos homéricos de pequena escala, como o são a proposição, a invocação divina e o

7 Conforme Cardoso, “A educação grega, em sua primeira fase, exige o manuseio de textos literários. É por meio deles que se procede à alfabetização da criança e que se ministram a ela as primeiras noções de história, geografia, ética, mitologia e religião. A não-existência de textos para esse fim levou Lívio Andronico a traduzir a Odisseia. (...) A tradução de Lívio Andronico, entretanto, por medíocre e rudimentar que fosse, ao lado de tornar o poeta conhecido da sociedade, colocou o romano em contato direto com um texto literário grego, e propiciou o aparecimento de outros poemas épicos." (CARDOSO, 2003, p. 8).

8 Um capítulo do grosso volume de Gordon Williams deixa-nos entrever muitos aspectos da mescla entre "grego" e "romano" como um dos traços mais frequentes da poesia latina. (cf. WILLIAMS, 1985, p. 250-357 - destaques do autor).

9 "Depuis les environs de 300 av. J.-C., le grand pontife inscrivait sur une planche blanchie (album), au forum, les événements quotidiens; le quadre étant fourni par le calendrier religieux (fasti), le surnaturel païen y tenait une grande place: éclipse de lune, prodiges divers; on admet que cette chronique indiquait aussi le cours du blé." (ANDRÉ; HUS, 1974, p. 9). 
início in medias res: ora, os sete primeiros versos do livro de abertura da Eneida se prestam a cumprir o papel proposicional neste épico, ou seja, de "resumo" dos intentos do poeta com a feitura do canto celebrativo correspondente ao todo do texto $;^{10}$ na Odisseia, por exemplo, os versos de um a cinco do canto I parecemnos cumprir o essencial do mesmo componente, pois, do sexto ao décimo terceiro, sucedem-se comentários sobre a má sina dos sacrílegos companheiros de Ulisses - devoradores do gado sagrado do Sol! -, nova interpelação à Musa (v. 10) e um cotejo entre o calmo destino dos que conseguiram tornar à pátria depois da Guerra de Troia e o do errante herói. ${ }^{11}$

Sobre a função das Musas em Homero, em específico na Ilíada, vale a pena lembrar:

Enquanto memória, a Musa volta-se para o passado, é ela própria memória do passado. Assim, consideram os especialistas, a assistência que o poeta pede à deusa refere-se, contrariamente ao que se costuma supor, não tanto à concessão de "engenho e arte" para compor o poema, mas principalmente à garantia de fidelidade à memória do que se canta. É certamente por isso que, nos momentos mais difíceis para a memória limitada e imperfeita do poeta, ele volta a suplicar o auxílio divino, como no segundo canto da Ilíada, antes de iniciar o chamado "catálogo das naus" (...). (Cf. BRANDÃO, 1992, p. 47).

Não nos parece, então, fortuito que, em v. 8 do canto I da Eneida, Virgílio peça à Musa que o faça lembrar-se - mihi causas memora, "lembra-me os motivos" - das causas das vicissitudes enfrentadas pelo herói de seu poema. Quanto ao início in medias res, enfim, esse grande épico romano o partilha com a Odisseia, na medida em que a narrativa (I, 34 et seq.), propriamente, inicia-se nele pelo relato da situação da frota de Eneias já em meio à viagem marítima para alcançar a Itália, não pelos eventos funestos da Guerra de Troia; o correlato grego citado, por sua vez, começa a focalização da trama pela lembrança de

10 Cf. VIRGÍlIO, Eneida I, 1-7: Arma uirumque cano Troiae qui primus ab oris/ Italiam, fato profugus, Lauinaque uenit/ litora: multum ille et terris iactatus et alto,/ ui Superum, saeuae memorem Iunonis ob iram;/ multa quoque et bello passus, dum conderet urbem,/ inferretque deos Latio: genus unde Latinum,/ Albanique patres, atque altae moenia Romae. - "Armas canto e o varão que, êxul de Troia,/ primeiro os fados prófugo aportaram/ na Hespérica Lavino. Em mar e em terra/ muito o encontrou violenta mão suprema,/ e o lembrado rancor da seva Juno;/ muito em guerras sofreu, na Ausônia quando/ funda a cidade e lhe introduz os deuses:/ donde a nação Latina e os Albanos padres/ e os muros vêm da sublimada Roma." (Tradução de Manuel Odorico Mendes)

$11 \mathrm{Na}$ Ilíada, porém, como explicado por Nely Pessanha, a proposição se encontra entre v. 1-7 do texto, de maneira entrelaçada à própria invocação à Musa (Cf. PESSANHA, 1992, p. 33). 
Ulisses enleado pelos encantos de Calipso na ilha de Ogígia (I, 14 et seq.). ${ }^{12}$

Ao passarmos à leitura d'Os Lusíadas, apesar das explícitas declarações de Camões de intentar "ultrapassar" os épicos greco-romanos, ${ }^{13}$ na verdade se nota que ele se encontra nada menos que alicerçado em sua prática poética pregressa. Como dissemos, vivia-se, na época do poeta português, em pleno Renascimento do século XVI, movimento cultural oriundo da Itália, precedido pelo Humanismo - tempo de intensa "redescoberta" dos clássicos greco-romanos e de tomada do homem para medida do Universo - e caracterizado por traços gerais afins à imitação ${ }^{14}$ dos autores pagãos do passado, ao prosseguimento em caminhos artísticos pautados por regras construtivas ordenadoras, ao racionalismo, à universalidade, à busca por grandes valores como o Belo, o Bem e a Verdade e ao culto à forma. (MOISÉS, 2005, p. 51-52).

À sua maneira, portanto, Camões constrói Os Lusíadas imitando complexamente as estrutura e os temas de obras antigas como a Ilíada (mas, sobretudo, a "marítima" Odisseia) e a Eneida: integra este épico renascentista o assunto da coragem lusa na viagem de descoberta das Índias, bem como dos feitos bélicos do mesmo povo (vejam-se os cantos III e IV, de narrativa da história portuguesa ao rei de Melinde, por Vasco da Gama), dão-lhe forma algumas "partes" já comentadas em Homero e Virgílio por seu caráter de fundamentos estruturais da

$12 \mathrm{O}$ mesmo não se dá exatamente na Ilíada, pois, ali, a narrativa do canto I é iniciada pelo começo do episódio focalizado na obra - a "ira de Aquiles"; Homero, com efeito, dá curso nesse contexto ao relato da peste sobre o exército grego, a qual se revela ter sido um castigo de Apolo, pois os helenos detinham como presa de guerra a donzela Criseida, filha de seu sacerdote. Assim, como se viu privado dessa moça para aplacar o ressentimento divino e fazer cessar a mortandade no acampamento, o rei Agamêmnon desejou tomar para si, em truculenta mostra de poder, Briseida, que antes se dera a Aquiles: na sequência, as dores do herói ofendido dessa forma determinaram-lhe a retirada do exército grego e o início de muitas calamidades para os seus, até que se decidisse por tornar de novo à batalha, já no canto XIX (desdobramentos da derrota de Pátroclo por Heitor).

13 Cf. CAMÕES, Os Lusíadas I, 3, 1-8: "Cessem do sábio grego e do troiano/ as navegações grandes que fizeram;/ cale-se de Alexandro e de Trajano/ a fama das vitórias que tiveram;/ que eu canto o peito ilustre lusitano,/ a quem Netuno e Marte obedeceram./ Cesse tudo o que a Musa antiga canta,/ que outro valor mais alto se alevanta." Trata-se, na verdade, de uma manifestação da aemulatio, "rivalidade", segundo a qual, no âmbito literário, um autor posterior tomava antecessores dignos de admiração com intentos de superar os seus feitos pela própria obra. (Cf. ARISTÓTELES, 2003, p. 70-71 (1388a)).

14 Conforme Moisés: “Imitar não significa copiar, mas, sim, a procura de criar obras de arte segundo as fórmulas, as medidas, empregadas pelos antigos. Daí a observância de 'regras', estabelecidas como verdadeiros suportes ou pressupostos da obra literária: os escritores não tinham mais que observá-las, acrescentando-lhes a força do talento pessoal." (MOISÉS, 2005, p. 51 - destaques do autor). 
poesia heroica, ${ }^{15}$ animam-no a mitologia ${ }^{16}$ e episódios menores que já se poderiam considerar presentes nos textos da Antiguidade tomados para ponto de referência...

Tal aspecto da retomada episódica constituirá justamente o objeto de nossos olhares na continuidade do artigo, pois, tomando para parâmetro de cotejo possível, sobretudo, Virgílio - talvez, uma das fontes essenciais da erudição do autor renascentista em pauta $^{17}$-, intentaremos estabelecer paralelos entre, por um lado, dois aspectos temáticos das estâncias 7 a 37 do canto VI d'Os Lusíadas e, por outro, das Geórgicas IV, 317-418 e da Eneida X, 1-117. Mais do que, assim, provar eventuais "influências" diretas de Virgílio sobre Camões, poder-se-á, por semelhante meio analítico, dar continuidade à observação da tradição clássica em plena e inequívoca vigência n'Os Lusíadas.

\section{Comentário dos temas clássicos da viagem a um reino submarino e do concílio dos deuses em Virgílio e em Os Lusíadas VI, 7-37}

O final do livro derradeiro das Geórgicas virgilianas, poema didático em geral ocupado do tratamento, em versos, das técnicas agrárias - plantio, viticultura, pecuária e apicultura -, apresenta ao leitor um artefato literário complexo: referimonos ao assim chamado epýllion ${ }^{18}$ de Orfeu e Aristeu, o qual vem preencher o fecho de toda a obra com a adoção de uma estratégia narrativa combinada. Ocorre, segundo elaborado por Virgílio no mesmo contexto, que a lenda de Orfeu, mítico inventor do canto e da poesia que desce ao Hades a fim de buscar a esposa morta, Eurídice, depois do trágico acidente dela com a pisada sobre uma serpente, surge imbricada à

15 Conforme Moisés: "Divide-se (Os Lusíadas) em três partes: 1'a., 'Introdução' (18 primeiras estâncias), subdividida em 'Proposição' (estâncias 1-3): o poeta se propõe cantar as façanhas das “armas e os barões assinalados”, isto é, os feitos bélicos de homens ilustres; 'Invocação' (estâncias 4-5): o poeta invoca as Tágides, musas do rio Tejo; 'Oferecimento' (estâncias 6-18): o poema é dedicado a D. Sebastião, a cujas expensas se deve a sua publicação; 2a.., 'Narração' (Canto I, estância 19 - Canto X, estância 144); 'Epílogo' (Canto X, estâncias 145-156).” (MOISÉS, 2005, p. 57).

16 Conforme Berardinelli, a respeito da "tolerância" da Censura inquisitorial com as partes mais sensuais do poema: "O bom frade não achara 'cousa alguma escandalosa', e, no entanto, como Miguel Ângelo, o poeta ousara trazer para sua obra a nudez sem disfarces que só se aceitava na arte pagã e, mais que o mestre florentino, bastante casto, descrevera ou narrara cenas carregadas de sensualidade, como as da Ilha dos Amores ou do encontro de Vênus e Júpiter.” (BERARDINELLI, 1992, p. 118).

17 Conforme Ramalho: "E, de fato, em Os Lusíadas a ilha dos Amores recorda os Campos Elíseos da Eneida. Mas uma descida aos Infernos, onde se situa o Elísio, implicava problemas teológicos mais graves do que uma ilha imaginária no meio do Oceano.” (RAMALHO, 1980, p. 74).

18 Conforme Howastson: “ Epyllion (diminutif grec de epos, 'épopée’). Nom donné, dans la littérature grecque et latine, à une très brève épopée. C'est un poème narratif de quelques centaines d'hexamètres portant généralement sur la vie d'un héros ou d'une héroïne mythique et plus particulièrement sur ses amours." (HOWATSON, 1993, p. 378). 
de Aristeu, pois esse último nos é apresentado pelo poeta romano como responsável involuntário pela morte da moça. Na versão virgiliana dos eventos, assim, Eurídice morreu porque, em fuga à perseguição amorosa de Aristeu nas margens verdejantes de um riacho, não viu o animal peçonhento que haveria de envenená-la.

Depois desse incidente e da tentativa frustrada do marido de recuperá-la ao mundo das Sombras, valendo-se, para isso, de seus extraordinários dotes artísticos (capazes de comover até os monstros, como o cão Cérbero, e deuses infernais, como o rei Plutão e a companheira Prosérpina!), Orfeu acaba em desvario, sendo enfim trucidado pelas Bacantes da Trácia em uma de suas andanças a esmo (v. 520 et seq.). Isso significou, na prática, a ruína dos dois cônjuges envolvidos, em uma sequência de desastres desencadeada pelo gesto passional de Aristeu diante da beleza da moça, justificando-se que as almas, ou manes, de ambos acabassem por vingar-se dele através de uma maldição que lhe dizimou as abelhas. Lembramos aqui que, como "deus civilizador", esse filho de Apolo e de uma ninfa fluvial chamada Cirene se reputara o descobridor mítico da apicultura, tendo ensinado seu métier aos homens.

Tais circunstâncias de perda dos enxames, sem que o desatento Aristeu pudesse relacioná-las à perseguição passada a Eurídice ou mesmo à morte dela e do esposo, que então o perdiam, fizeram com que esse apicultor procurasse a mãe, a fim de obter ajuda para o mal a afligi-lo: a saber, ela lhe aconselha buscar o deus Proteu, sabedor de todas as coisas, e indagar as causas do problema. Depois que Proteu revela que tudo se trata de uma vingança dos manes ofendidos de Orfeu e Eurídice, segue-se a condução de um rito purificador, a bougonía, a fim de aplacá-los; contudo, desta vez a própria Cirene ajuda o filho a conduzi-lo (v. 531 et seq.), enfim ocorrendo, com a aceitação do gesto sagrado pelo casal, o pleno renascimento das abelhas de Aristeu.

Bem mais do que o desfecho da aventura assim imaginada por Virgílio, porém, interessa-nos presentemente focalizar o aspecto do relato que se vincula, no mito de Aristeu, à viagem até os reinos de sua mãe. Esses se localizavam, segundo a descrição do poeta romano, com entrada sob a fonte do rio Peneu, no vale tessálico de Tempe (v. 317-320). Quando ele se detém ali e clama lastimoso por Cirene (v. 321-332), ouvem-se ruídos no fundo, mas em princípio não se atina com o autor do pranto, até que uma das ninfas locais, Aretusa, projeta a "cabeça loira" (flauom caput, v. 352) acima da superfície e, vendo-o, anuncia.

É importante explicar que a demora em atender ao chamado de Aristeu à sua mãe - ele apenas adentra, de fato, o reino das águas em v. 360 - se deve ao fato de outra ninfa, Climene, contar na ocasião interessante relato mítico, inclusive sobre os amores de Marte e Vênus, à corte subaquática de deusas que fiavam em sossego ao lado de Cirene, patenteando-se, assim, o caráter envolvente de seu 
relato (v. 345). Virgílio ainda aproveita a oportunidade para enumerar na corte várias ninfas (Drimo, Xanto, Ligeia, Filódoce, Neseia, Éspio, Talia, Cimódoce, Cidipe, Licoríade, Clio, Béroe, Éfira, Ópis e Deiopeia) além das que citamos, em mostra de significativa erudição mítica, à maneira dos poetas alexandrinos a que, em muitos pontos, também seguiu. (WILKINSON, 1997, p. 60-63).

A chegada efetiva do herói ao reino subaquático, por sua vez, é apresentada assim:

Duc age, duc ad nos; fas illi limina diuom tangere”, ait. Simul alta iubet discedere late flumina, qua iuuenis gressus inferret: at illum curuata in montis faciem circumstetit unda accepitque sinu uasto misitque sub amnem. Iamque domum mirans genitricis et umida regna speluncisque lacus clausos lucosque sonantis ibat et ingenti motu stupefactus aquarum

omnia sub magna labentia flumina terra spectabat diuersa locis, Phasimque Lycumque et caput, unde altus primum se erumpit Enipeus saxosusque sonans Hypanis Mysusque Caicus, unde pater Tiberinus et unde Aniena fluenta, et gemina auratus taurino cornua uoltu Eridanus, quo non alius per pinguia culta in mare purpureum uiolentior effluit amnis. ${ }^{19}$

O original latino, ou a tradução poética de António Feliciano de Castilho, em ambos os casos permitem entrever que, aparentemente, Aristeu passa ao mundo das águas a seco, de modo de todo fantástico: ${ }^{20}$ ele não tem, na verdade, de nadar ou mergulhar para lograr esse intento. Uma vez que ele penetra naquele ambiente estranho, nota-se na passagem citada o início das descrições do que vê, como

19 Cf. VIRGÍLIO, Geórgicas IV, 358-373: "Vai, corre, voa, traze-o, exclama; sem receio/ na divina mansão penetre!" Incontinenti/ ao rio ordena abrir-lhe a túmida corrente,/ e a veia para logo em serras apartada,/ outorgando ao mancebo ampla e segura estrada,/ chegar o deixa ileso aos subequóreos paços,/ reinos da sacra mãe. Nos úmidos espaços/ com que assombros não vaga! Aqui, acha as cavernas/ das lagoas tesouro; além, selvas infernas/ rumorejando; pasma ouvindo o estrondo horrendo/ de quantos rios vão mansíssimos correndo/ por sob a grande terra, à vista humana ignotos,/ por tão várias regiões e em sítios tão remotos:/ Fásis; Lico; a matriz do Enípeo undoso e fundo;/ a do pai Tiberino, um dia rei do mundo;/ a dos caudais do Anieno; o Hipane em fragas bravo; o Caíco da Mísia; o Erídano auriflavo/ na tauricórnea fronte, o que a nenhum dos rios/ violento cede a palma em generosos brios,/ quando por férteis chãos mimosos de cultura/ se leva contra o mar que a luz do sol púrpura." (Tradução de António Feliciano de Castilho).

20 Cf. VIRGÍLIO, Geórgicas IV, 360-362: "Mas a ele/ a onda curvada à maneira de um monte envolveu,/ acolheu no vasto seio e mandou abaixo do rio." 
"lagos", "cavernas" e "florestas" de plantas marinhas, como se se tratasse de uma réplica do ambiente terrestre; ainda, o poeta claramente preferiu enfatizar, ao descrever tais imagens, o elemento fluvial, como se os rios, que brotam do fundo da terra, pudessem ser vistos - spectabat, "observava", v. 367 - em conjunto de onde se punha o herói.

Quanto aos ambientes internos dos domínios de Cirene, ou seja, a seu próprio palácio, em passagens anteriores já se aludira a um dado cromático e ao material de feitura da mobília, ${ }^{21}$ harmonizando-se os dois elementos com a natureza aquática do espaço onde se situam nos quesitos de cor e transparência, respectivamente. Depois do trecho que transcrevemos, por outro lado, ainda se oferecem mais dados a respeito dessa parte do ambiente aquático, como ao dizer que possui tetos de pedra-pome - pendentia pumice tecta, "tetos em dossel de pedra-pome", v. 374 -, que as irmãs de Aristeu o servem ali, ajudando-o a lavar e secar (!) as mãos e pondo bebida e comida à mesa (v. 376-379), e que arde o fogo sobre um altar, no qual, em seguida, far-se-á uma libação (v. 379-385). Acreditamos que a focalização concentrada nos aspectos sensoriais, sobretudo da visualidade, em toda a cena da viagem de Aristeu à casa de sua mãe (ressalva feita aos v. 386-418, basicamente preenchidos por um discurso instrutivo da ninfa e pelo preparo do filho para "arguir" o esquivo Proteu) decorre do próprio inusitado dessa experiência imaginária, de modo que narrar sobre as formas de um mundo jamais visto pelos leitores do tempo de Virgílio significou, para ele, uma chance de instigar-lhes o interesse.

No próprio Camões, o correlato dos versos virgilianos que temos visto surge nas estâncias 7-15 do canto sexto d'Os Lusíadas, quando Baco, mítico inimigo dos portugueses, pelo receio de perder o renome de suas antigas conquistas no Oriente $^{22}$ caso viessem a descobrir o caminho para as Índias, vai solicitar ajuda a Netuno, intentando, através de uma tempestade suscitada com o aval do soberano dos mares, fazer naufragar a esquadra de Vasco da Gama. É válido citar ao menos duas estrofes da passagem, com vistas a compará-las seguramente com Virgílio:

No mais interno fundo das profundas cavernas altas, onde o mar se esconde, lá donde as ondas saem furibundas quando às iras do vento o mar responde,

21 Cf. VIRGÍliO, Geórgicas IV, 335 e 350: hyali saturo fucata colore - "(velos) tingidos na cor carregada do verde"; uitreisque sedilibus - "e nos assentos de vidro".

22 Conforme Grimal: “De Thrace, Dionysos gagna l'Inde, pays qu'il conquit au cours d'une expédition mi-guerrière, mi-divine, soumettant les pays par la force de ses armes (car il avait avec lui une armée), et aussi par ses enchantements et sa puissance mystique." (GRIMAL, 1963, p. 127). 
Netuno mora e moram as jucundas

Nereidas e outros deuses do mar, onde

as águas campo deixam às cidades

que habitam estas úmidas deidades.

Descobre o fundo nunca descoberto

as areias ali de prata fina;

torres altas se veem, no campo aberto,

de transparente massa cristalina;

quanto se chegam mais os olhos perto

tanto menos a vista determina

se é cristal o que vê, se diamante,

que assim se mostra claro e radiante.

Essa descrição camoniana "repete" alguns pontos da passagem vista de Virgílio, na medida que também surgem, aqui, além do "empréstimo" do olhar do viajante (Baco) para o leitor, as "cavernas" subaquáticas, a ideia do fundo do mar como a morada de uma corte de deuses - que inclui as Nereidas ${ }^{23}$ e Netuno -, a menção a serem feitos certos objetos de vidro/ cristal (ou diamante), a aproximação visual entre o ambiente marinho e a superfície... No tocante ao último aspecto de coincidência entre ambos o poetas, assim referido, na verdade se trata de uma "retomada" apenas parcial, pois, em Virgílio, o mundo das águas parecia-se com as terras sobretudo por conter, como elas, elementos paisagísticos naturais do tipo dos lagos, florestas, cavernas e rios, bem o vimos; em Camões, além das águas, os dois outros elementos naturais associáveis ao fundo - "cavernas" e "areias de prata fina" -, embora possam ajudar a compor o aspecto do mundo emerso, também constituem componentes comuns do submerso, obviamente... Em contrapartida, o mesmo poeta renascentista faz o esboço das "cidades" no reino de Netuno, cujas "torres altas se veem, no campo aberto,/ de transparente massa cristalina". Com isso, julgamos, o gesto de destacar elementos da civilização na paisagem, de outra forma, selvagem dos mares profundos contribui para imprimir nota de independência criativa ao relato de Camões, intensificando-se esta impressão quando lembramos, na parte mais visual do relato da viagem subaquática em Virgílio, suas referências a tantos rios (o Fásis, o Lico, o Erídano...) da geografia antiga e a continuidade das descrições camonianas no sentido da cobertura a um peculiar elemento arquitetônico. ${ }^{24}$

23 Conforme Grimal: "Les Néréides sont des divinités marines, filles de Nérée et de Doris, et petitefilles d'Océan. Elles personnifient, peut-être, les vagues innombrables de la mer." (GRIMAL, 1963, p. 314).

24 Outra diferença que julgamos importante entre a descrição do mundo subaquático em Virgílio, no episódio aqui tratado, e em Camões, diz respeito a alguma paradoxal impressão de secura encontrada 
Esse é a própria porta dos domínios de Netuno, a que o poeta português dedica as estâncias 10-13 do mesmo canto VI d'Os Lusíadas, primeiro descrita na preciosidade dos materiais de que é feita ("aljôfar", v. 2 da estância 10) e com a figura de Caos, velha divindade mitológica pré-olímpica (v. 5-6 da estância 10); depois, a estância seguinte dedica quatro versos ao elemento fogo e quatro ao ar, na porta representados; em seguida, a estância 12 esgota este recurso à figuração elementar pela abordagem da terra e das águas; por último, a estância 13 focaliza a parte que continha as figuras da guerra dos Gigantes contra os deuses do Olimpo, o dom lendário de Minerva aos homens - a oliveira - e o de Netuno - o cavalo.

Camões evidentemente se vale, para a construção desta parte específica de seu poema épico, do recurso clássico da ékphrasis/ descriptio, ${ }^{25}$ que vem a ser, no sentido antigo dos termos grego ou latino, servir-se das palavras para a "pintura" imaginária de um objeto qualquer. ${ }^{26}$ As estâncias 14-15 mostram-nos a efetiva chegada de Baco à morada de Netuno, porém não se diz muito a respeito do modo da recepção, exceto que esse "às portas o recebe, acompanhado/ das ninfas, que se estão maravilhando/ de ver que, cometendo tal caminho,/ entre no reino da água o Rei do vinho" (v. 5-8 da estância 14). ${ }^{27}$ Além disso, nas estâncias 16-19, que ainda compõem o trecho da viagem submarina de Baco, Camões se

na obra do poeta romano, mas não na do português: o último autor, assim, fala explicitamente em "estas úmidas deidades" e "uns limos prenhes d'água" (v. 8 da estância 8 e v. 3 da estância 17) no trecho correspondente. Virgílio, por sua vez, apresenta ao leitor mais de um elemento que dá a entender que aquele ambiente não era tão úmido quanto se pensaria: além da chegada "em seco" de Aristeu ao fundo do rio Peneu, como explicamos, no palácio de Cirene suas irmãs lhe oferecem água e toalhas para higienizar-se (v. 376-377), além de ali arder forte o fogo de Vesta sobre os altares (v. 384-385).

25 Uma ékphrasis, precisamente, de uma porta foi composta por Virgílio, recordamos, em Geórgicas III, 26-33. Trata-se da descrição de um detalhe do templo que o poeta promete edificar em sua pátria, a cidade itálica de Mântua, em provável alusão metafórica à escrita de um futuro poema épico-heroico (a Eneida?): In foribus pugnam ex auro solidoque elephanto/ Gangaridum faciam uictorisque arma Quirini/ atque hic undantem bello magnumque fluentem/ Nilum ac nauali surgentis aere columnas./ Addam urbes Asiae domitas pulsumque Niphaten/fidentemque fuga Parthum uersisque sagittis/ et duo rapta manu diuerso ex hoste tropaea/ bisque triumphatas utroque ab litore gentis. - "Do templo nos portões porei, com talha de ouro/ sobre lácteo marfim, do Ganges o desdouro,/ lustre do vencedor, meu Rômulo segundo./ Ajuntarei o Nilo undívago e profundo/ todo em guerra a ferver; e logo ali cativo/ o naval bronze hostil formando redivivo/ colunas triunfais. Não deixarei no escuro/ tantas cidades da Ásia aos pés do Marte duro:/ o Nifate repulso; os Partos, à fugida/ e ao setear de após fiando embalde a vida;/ dois troféus numa destra, a gentes arrancados/ de opostas regiões: dois povos triunfados,/ um do ocaso, um da aurora. (...)" (Tradução de António Feliciano de Castilho)

26 Conforme Pernot: "On peut décrire des personnes, des actions, des lieux, des saisons, des oeuvres d'art... Ex. 'description d'une guerre' (la description, quand elle porte sur une action, recoupe dans une certaine mesure la narration).” (PERNOT, 2000, p. 196).

27 O espanto das Nereidas com a visita de Baco ao mar, ambiente tão estranho aos seus hábitos de vida, parece-nos aqui reforçado pela antítese entre "água" e "vinho". 
dedica a detalhada apresentação/descrição do deus menor Tritão, filho de Netuno e de Salácia, o qual se encarregará de convocar os demais entes aquáticos depois de o visitante ter anunciado, na estância 15, uma "desventura" (v. 7), ou seja, os recentes sucessos dos portugueses, a exigir rápida reparação:

Os cabelos da barba e os que descem

da cabeça nos ombros, todos eram

uns limos prenhes de água, e bem parecem

que nunca brando pente conheceram.

Nas pontas pendurados não falecem

os negros mexilhões, que ali se geram.

Na cabeça, por gorra, tinha posta

uma mui grande casca de lagosta.

Passando ao segundo tema clássico do conjunto considerado das estâncias do canto VI, o qual se dá em Camões entre aquelas de número 20 e 37 (mas surge, em Virgílio em Eneida X, 1-117), lembramos vincular-se ao elemento temático do concílio, ou reunião divina em "assembleia". No próprio Virgílio, esse episódio surge como desdobramento dos três cantos anteriores de sua epopeia, pois se trata, particularmente, de uma assembleia entre os deuses para decidir os destinos da guerra que se desencadeara há pouco entre, por um lado, o forasteiro Eneias e seus aliados - como o próprio Evandro e os "árcades", estabelecidos na Itália - e, por outro, Turno e os rútulos (ou latinos). Lembramos, aqui, que o nobre troiano fora predestinado pelos fados a encontrar na Itália uma nova pátria para seu povo remanescente do massacre dos gregos na Dardânia, mas, para isso, primeiro teria de derrotar Turno, que também se interessava, como ele, pela mão da princesa Lavínia, filha de Latino, o soberano local.

Assim, quando Eneias se encontrava distante de seu povo, depois do desencadeamento original dos conflitos por ardis da deusa Juno (canto VII) e em "embaixada" conciliadora de aliados (canto VIII), Turno efetua um fulgurante ataque contra os troianos (canto IX): nesta ocasião, sucedem muitas perdas graves para as tropas dos "forasteiros", como as que se descrevem em v. 314467, e dizem respeito ao lance aventuresco das mortes dos jovens Niso e Euríalo, amigos inseparáveis na vida e na morte. Desse modo, o descontentamento de Júpiter, que vedara a deflagração de guerras entre o povo de Eneias e os demais, mas via descumpridos na peleja os seus desígnios, fez com que chamasse a corte celeste ao concílio a que nos temos referido, a fim de se determinar em comum uma direção para os conflitos.

Pode-se dizer que quatro discursos contínuos dominam a mesma passagem 
da Eneida, seguindo-se o de Venus (v. 18-61) a uma primeira fala breve de Júpiter (v. 6-15), mas sendo seguido daquele de Juno, em contra-ataque (v. 6395); ao fim, de novo Júpiter retoma a palavra resumidamente (v. 104-113), para deixar "ao destino" a resolução da guerra que viam iniciar-se. ${ }^{28}$ A posição de Vênus, mãe de Eneias e tradicional defensora dos troianos em muitos lances críticos,$^{29}$ basicamente se vincula, aqui, a lamentar-se ao pai dos ataques que vinham sucedendo a esse povo, como se, mais do que arrastados à Itália pela inexorável cadeia de eventos pré-determinados, os seus estivessem, com suas andanças, sobretudo incorrendo no desagrado de Júpiter:

Si sine pace tua atque inuito numine Troes
Italiam petiere; luant peccata, neque illos
iuneris auxilio. Sin tot responsa secuti,
quae Superi Manesque dabant; cur nunc tua quisquam
uertere iussa potest? Aut cur noua condere fata?

O discurso de Juno, que se constrói como virulento rebate ao de Vênus, explicamos, reveste-se de algumas características que vale a pena ressaltar. Assim, enquanto a "deusa do amor" se queixa indiretamente das culpas de Juno nos sofrimentos de seu filho, de seu neto - Ascânio, que Eneias tivera em Troia da esposa Creúsa - e, em geral, de todo o povo remanescente do desastre na Dardânia, a consorte de Júpiter, ciente de ter sido objeto dos ataques, responde-lhe com diretas palavras: isso ocorre não só pelo emprego gramatical da segunda pessoa do singular ${ }^{31}$ mas também por se trazerem à tona

28 Cf. VIRGÍlLIO, Eneida X, 105-113: "Quandoquidem Ausonios coniungi foedere Teucris/ haud licitum, nec uestra capit discordia finem;/ quae cuique est fortuna hodie, quam quisque secat spem,/ Tros Rutulusue fuat, nullo discrimine habebo;/ seu fatis Italum castra obsidione tenentur,/ siue errore malo Troiae monitisque sinistris./ Nec Rutulos soluo; sua cuique exorsa laborem/ fortunamque ferent: rex Iuppiter omnibus idem;/ fata uiam inuenient." - "[...] Já que é defeso/ Teucros e Ausônios congraçar, nem finda/ vossa discórdia, esperançoso corra/ seus fados cada qual, desde hoje trato/ sem diferença a Rútulo ou Dardânio;/ quer à Hespéria nocivo ature o assédio,/ quer por erro de agouro em mal de Troia,/ jogado o lanço foi: rei justo às partes,/ Júpiter os destinos não desliga;/ Estes rumo acharão." (Tradução de Manuel Odorico Mendes)

29 Conforme Grimal: "Pendant toute la guerre, elle accorde sa protection aux Troyens, et à Paris, en particulier.” (GRIMAL, 1963, p. 40).

30 Cf. VIRGÍLIO, Eneida X, 31-35: "Se a teu pesar estão na Hespéria os nossos,/ não mos ajudes, seu delito expurguem;/ se lei cumprem superna e a voz dos Manes,/ como inda há quem transverta as ordens tuas/ e reforme o destino? [...].” (Tradução de Manuel Odorico Mendes)

31 Cf. VIRGÍLIO, Eneida X, 94-95: Tunc decuit metuisse tuis; nunc sera querelis/ haud iustis assurgis, et irrita iurgia iactas. - "Teu medo então convinha; tarde surges/ com injusto queixume e fútil bulha." (Tradução de Manuel Odorico Mendes) 
pesadas acusações pessoais. ${ }^{32}$ A rainha dos deuses, ainda, em sua tentativa de transferir toda a culpa pelos problemas de que se queixa Vênus, além de para ela própria, também para o povo de Troia, produz em sua fala um série de distorções dos fatos, como, por exemplo, ao dizer que os troianos apenas seguiram à Itália por confiarem nas palavras da desvairada Cassandra (v. 66-67) - algo de todo insensato, segundo o mito a envolver o castigo de Apolo a essa filha de Príamo! ${ }^{33}-$ e que o "irresponsável" Eneias deixara o comando dos acampamentos de seu povo a um menino, Ascânio (v. 70). ${ }^{34}$ A rispidez da atitude de Juno e a virulência de suas palavras na ocasião bem se coaduna, devemos dizer, com o caráter rancoroso dessa deusa e com o proverbial ódio que nutria pelo povo de Troia, depois de episódios como a concessão, por Páris, da primazia da beleza a Vênus, não a ela ou a Minerva, em um concurso (HOWATSON, 1993, p. 721) e do rapto do bonito Ganimedes por Júpiter, para servir de escanção dos deuses no Olimpo... ${ }^{35}$

O concílio divino do canto VI d'Os Lusíadas, tema, na literatura de moldes clássicos, já desenvolvido de outros modos, além de por Virgílio, pelo próprio Camões (canto I, 20-41) e por Homero (Ilíada, canto IV, 1-74; Odisseia, canto I, 19-95...), assume, neste poeta português, traços peculiares. Além do fato de se tratar de uma reunião dos deuses do/no mar - algo inaudito em seus antecessores da Antiguidade nas passagens épicas que citamos -, o cotejo com a iniciativa de escrita virgiliana nos mostra que Camões concentra a estrutura de sua versão desses eventos em duas partes bem distintas: a primeira delas diz respeito ao "catálogo" de divindades marinhas que acudiram ao chamado de Netuno, através do mensageiro Tritão (estâncias 20-24), e inclui, além de Netuno, Oceano, Nereu, Proteu, Tétis, Anfitrite, Ino, Melicerta e Glauco. Nessas circunstâncias, o poeta luso oferece algumas características físicas, psíquicas e míticas dos mesmos deuses,

32 Entre os versos 90-93, Juno lança à face de Vênus que o motivo de todas as desordens advindas da Guerra de Troia fora, na verdade, a paixão adúltera instigada por ninguém menos que ela em Páris, raptor de Helena da casa de seu marido, o rei Menelau de Esparta. Como sabemos, os pretextos para se ter dado início à contenda foram os intentos dos barões gregos ofendidos de, em conjunto, "resgatarem" essa mulher da posse indevida pelos inimigos.

33 Apolo se enamorara da princesa Cassandra, filha do rei Príamo de Troia: essa, porém, rejeitou-o, fazendo com que ele a castigasse com nunca ser acreditada por ninguém em suas profecias, apesar de elas serem absolutamente verdadeiras. (Cf. GRIMAL, 1963, p. 80-81).

34 Veja-se nota à passagem virgiliana correspondente, na tradução de autoria de José Vitorino Barreto Feio e José Maria da Costa e Silva: "Juno, para desconceituar Eneias e torná-lo ridículo por sua imprudência, diz que deixara a direção do seu acampamento e a suma de guerra nas mãos de uma criança; mas Eneias estava mui longe de haver cometido essa falta, pois em sua ausência deixava o comando encarregado não a seu filho Ascânio, mas sim a Seresto e Mnesteu, e a outros capitães de igual crédito e experiência.” (VIRGílLIO, 2004, p. 425 - nota 141).

35 Conforme Grimal : "Sa beauté (Ganymède passait pour 'le plus beau des Mortels') avait inflammé d'amour le plus puissant des dieux." (GRIMAL, 1963, p. 163). 
diferenciando, ainda, que na ocasião se assentaram "as deusas em riquíssimos estrados/ os deuses em cadeiras de cristal". (v. 3-4 da estância 25).

Logo na estância 27, Baco inicia o único discurso - a segunda parte do episódio deste concílio camoniano a que nos referíamos acima - do trecho em tons parecidos com a queixa de Vênus em Virgílio, pois, na verdade, expõe diante de todos os entes sagrados presentes sua dor com os fatos que o contrariam, vale dizer, a chegada dos portugueses tão longe na rota ao leste. ${ }^{36}$ Tais sucessos desses navegantes, intenta explicar a seus ouvintes, constituem perigo não só para a autoridade comum sobre o elemento líquido, pois representam uma espécie de ultrapassagem dos limites até então concedidos aos homens, ${ }^{37}$ mas ainda, fundamentalmente, para a glória de seus feitos individuais no antigo domínio daquela parte do mundo:

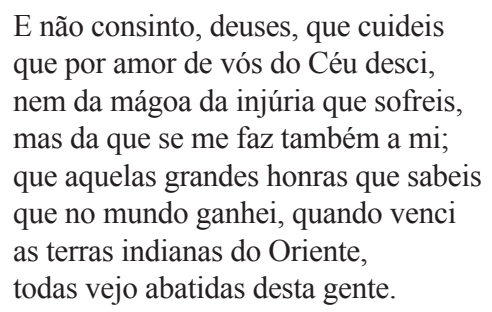

Após o fim da fala de Baco, que irrompe em lágrimas diante de sua dor - v. 6-8 da estância 34 -, logo se dissolve esta assembleia marinha, pois as palavras do deus e, sobretudo, seu pranto causaram tamanha revolta aos ouvintes que logo se ordena a Éolo, rei dos ventos, ${ }^{38}$ soltar seus súditos, para mal da segurança da esquadra portuguesa. Esse recurso ao mito do chefe dos ventos, instigado a devassar as portas de seus domínios para prejudicar os inimigos de alguma divindade, já fora bem desenvolvido por Virgílio, importa lembrar, em outra conhecida passagem da Eneida: referimo-nos ao que se dá no canto I, v. 54-95, quando a mesma Juno intercede junto a Éolo a fim de ocasionar uma tempestade e provocar a ruína da esquadra de Eneias. Parece-nos, assim, de maneira semelhante ao apontado a respeito da feitura da ékphrasis da porta dos reinos de Netuno quando Baco

36 Neste ponto da narrativa, os navegantes lusos tinham zarpado de Melinde, cidade da costa do Quênia, às margens do Oceano Índico, e já se encontravam "nos mares da Índia" (v. 2 da estância 6).

37 Cf. CAMÕES, Os Lusíadas VI, 29, 1-8: "Vistes que, com grandíssima ousadia,/ foram já cometer o céu supremo;/ vistes aquela insana fantasia/ de tentarem o mar com vela e remo;/ vistes, e ainda vemos cada dia,/ soberbas e insolências tais, que temo/ que do mar e do céu, em poucos anos,/ venham deuses a ser, e nós, humanos."

38 Conforme Howtson: “ Éole. Dans l'Odyssée, Homère en fait le fils d'Hippottès, un mortel, ami des dieux, à qui Zeus donne la maîtrise des vents. Il fut plus tard assimilé au dieu des Vents. Il vivait sur l'île flottante d'Éolia." (HOWATSON, 1993, p. 364). 
chega àquele mundo submerso, ${ }^{39}$ que elementos oriundos de mais de uma "matriz" clássica possível adentram este específico episódio d’Os Lusíadas; se continuarmos livremente este raciocínio, sem compromissos de buscar em Camões a derivação de partes inequívocas de Virgílio, ou de qualquer outro poeta clássico pregresso, também notaremos que o gosto por demonstrar erudição mitológica, por exemplo acumulando os nomes dos deuses das águas, já fora algo encontrado não no canto $\mathrm{X}$ da Eneida, mas no livro IV das Geórgicas, quando se falou da composição da corte de Cirene (v. 334 et seq.)...

As estâncias 35-36 do mesmo canto VI de Camões marcam, de maneiras distintas, dois "silenciamentos" das personagens envolvidas na assembleia, pois a palavra direta não é concedida a Netuno na primeira delas, apenas se dando a entender que partilha com os deuses a revolta pelos fatos trazidos à tona por Baco, e que segue mensagem destrutiva de sua parte ao responsável pela tutela dos ventos, ${ }^{40}$ além disso, na segunda estância do par, quando Proteu, deus associado ao dom da onisciência, como explicamos, tentava dizer algo (uma profecia?), foi subitamente calado por Tétis. ${ }^{41}$ Assim, acreditamos em que a partição "binária" aludida da cena do concílio camoniano, bem como a menor ênfase nos discursos das personagens seja porque apenas fala Baco, seja porque o fim desse trecho "cala", por diferentes artifícios, tanto Netuno quanto Proteu -, de novo indicam a segura independência criativa do poeta renascentista diante do antecessor romano.

\section{Conclusão}

Os exemplos e passagens comentados, não só de Camões, mas também de Virgílio e Homero, permitem observar na própria letra dos textos a tradição clássica como uma contínua tarefa de reelaboração pelos criadores. Tendo-se, assim, iniciado na Grécia antiga e passado pelos romanos, que já souberam imprimir as marcas de sua cultura e visão de mundo ao legado helênico, as seminais ideias atinentes a tal forma de moldar os objetos artísticos foram de novo revitalizadas durante o Renascimento europeu do século XVI, vindo Os Lusíadas a corresponder a uma de suas mais brilhantes realizações literárias. (BLOOM, 2002, p. 510).

39 Cf. supra nota 26.

40 Cf. CAMÕES, Os Lusíadas X, 35, 5-8: “Ao grande Eolo mandam já recado,/ da parte de Netuno, que sem conto/ solte as fúrias dos ventos repugnantes,/ que não haja no mar mais navegantes!"

41 Cf. CAMÕES, Os Lusíadas X, 36, 1-8: "Bem quisera primeiro ali Proteu/ dizer, neste negócio, o que sentia; e, segundo o que a todos pareceu,/ era alguma profunda profecia./ Porém tanto o tumulto se moveu,/ súbito, na divina companhia,/ que Tétis, indignada, lhe bradou:/ - Netuno sabe bem o que mandou!" 
Fazendo nossas as palavras de Costa Ramalho sobre o épico maior de nosso idioma, então, reconhecer que Camões se nutre, ou apropria, de elementos que não são meramente seus, mas trabalhados a partir de fontes comuns da cultura Ocidental, de modo algum significa o apagamento de seus méritos de vigoroso criador. Antes,

Quando um classicista procura as fontes greco-latinas de Camões ou de qualquer outro poeta moderno, não pretende diminuí-lo, mas exaltá-lo, na amplitude do seu convívio espiritual com a Antiguidade. (RAMALHO, 1980, p. 73).

Além disso, as análises acima demonstraram que, mesmo ao desenvolver episódios "idênticos" aos de obras como a Eneida e as Geórgicas, Camões não se restringe a reproduzir, mas altera, acrescenta ou suprime elementos à sua maneira. Enfim, sem pretender que as passagens virgilianas escolhidas para possíveis pontos de cotejo com o épico luso tenham correspondido às únicas e inequívocas fontes de Camões, estamos, porém, seguros de que o conhecimento dos recursos poéticos do vate romano decerto integrou o universo de toda a alta cultura do Renascimento, autorizando-nos, portanto, ao menos a aventar as hipotéticas relações que propusemos neste artigo. ${ }^{42}$

\section{RÉSUMÉ}

Dans cet article, notre but est de montrer la manière dont est faite l'introduction de deux thèmes classiques dans le sixième chant d'Os Lusíadas, de Luís de Camões (1572). Cela se produit, dans le livre mentionné, tout au long des strophes 7-37, dans lesquelles se développe aussi bien le sujet du voyage à un royaume divin sous les eaux que celui du concile des dieux marins. De tels développements camoniens trouvent des «antécédents» possibles, comme nous essaierons de le montrer, dans le quatrième livre des Géorgiques de Virgile - la visite d'Aristée à la nymphe Cyréné (v. 317-418) - et dans le dixième chant (v. 1-117) de l'Énéide du même poète

42 Conforme Ramalho: "Este foi em Camões muito extenso e, por isso, difícil se torna, como atrás dizia, encontrar um modelo único para os episódios de inspiração greco-latina, tanto mais que, além dos escritores da Hélade (possivelmente, em tradução latina) e de Roma, há que ter em conta intermediários como os humanistas e os escritores modernos até o seu tempo." (RAMALHO, 1980, p. 73). 
romain. Ainsi, la lecture comparée de ces morceaux mentionnés de Camões et Virgile nous donne des moyens concrets d'observer la «tradition classique» en opération dans l'oeuvre de cet auteur de la Renaissance portugaise.

Mots-clés: Tradition classique. Os Lusíadas. Virgile. Voyage subaquatique. Concile divin.

Referências

ANDRÉ, Jean-Marie; HUS, Alain. L'histoire à Rome. Paris: Presses Universitaires de France, 1974.

ARISTÓTELES. Retórica das paixões. Tradução de Ísis B. B. da Fonseca. São Paulo: Martins Fontes, 2003.

BERARDINELLI, Cleonice. "Os Lusíadas": a epopeia de uma época de contradições. In: APPEL, Myrna Bier; GOETTEMS, Míriam Barcellos. (Org.). As formas do épico. Porto Alegre: Editora Movimento, 1992, p. 116-128.

BLOOM. Harold. Genius: a mosaic of one hundred exemplary creative minds. New York: Warner Books, 2002.

BRANDÃO, Jacyntho Lins. Primórdios do épico: a Ilíada. In: APPEL, Myrna Bier; GOETTEMS, Míriam Bier. (Org.). As formas do épico. Porto Alegre: Editora Movimento, 1992, p. 40-55.

CAMÕES, Luís Vaz de. Os Lusíadas. São Paulo: Cultrix, 1991.

CARDOSO, Zélia de Almeida. A literatura latina. São Paulo: Martins Fontes, 2003.

GRIMAL, Pierre. Dictionnaire de la mythologie grecque et romaine. Paris: Presses Universitaires de France, 1963.

GRIMAL, Pierre. La littérature latine. Paris: Fayard, 1994.

HAUSER, Arnold. História social da arte e da literatura. Tradução de Álvaro Cabral. São Paulo: Martins Fontes, 2003.

HOMERO. Ilíada. Tradução de Carlos Alberto Nunes. Rio de Janeiro/São Paulo: Ediouro, 2002.

HOMERO. Odisseia. Trad. Trajano Vieira. São Paulo: Editora 34, 2011.

HORACE. Satires, epistles and "Ars poetica". With an English translation by H. S. Fairclough. London/ Cambridge, Mass.: Heinemann/ Harvard University 
Press, 1926.

HOWATSON, M. C. Dictionnaire de l'Antiquité. Trad. Jeannie Carlier et alii. Paris: Robert Laffont, 1993.

KURMAN, G. Ecphrasis in epic poetry. Comparative literature, Eugene, vol. 26, n. 1, p. 1-13, winter 1974.

MOISÉS, Massaud. A literatura portuguesa. São Paulo: Cultrix, 2005.

PEIXOTO, Afrânio. Ensaios camonianos. Rio de Janeiro/São Paulo/ Porto Alegre: W. M. Jackson, 1947.

PERNOT, Laurent. La rhétorique dans l'Antiquité. Paris: Le Livre de Poche, 2000.

PESSANHA, Nely Maria. Características básicas da epopeia clássica. In: APPEL, Myrna Bier; GOETTEMS, Míriam Barcellos. (Org.). As formas do épico. Porto Alegre: Editora Movimento, 1992, p. 30-39.

RAMALHO, Américo da Costa. A Ilha dos Amores e o Inferno virgiliano. In: RAMALHO, Américo da Costa. Estudos camonianos. Lisboa: Instituto Nacional de Investigação Científica, 1980, p. 73-83.

VASCONCELLOS, Paulo Sérgio de. Efeitos intertextuais na "Eneida" de Virgílio. São Paulo: Humanitas/ Fapesp, 2001.

VIRGILE. Géorgiques. Texte traduit par E. de Saint-Denis, introduction, notes et postface de J. Pigeaud. Paris: Les Belles Lettres, 1998.

VIRGÍLIO. Geórgicas; Eneida. Tradução de António Feliciano de Castilho e Odorico Mendes. Rio de Janeiro: W. M. Jackson, 1949.

VIRGÍlLIO. Eneida. Tradução de José Vitorino Barreto Feio e José Maria da Costa e Silva, edição organizada por Paulo Sérgio de Vasconcellos. São Paulo: Martins Fontes, 2004.

VIRGÍLIO. Eneida brasileira. Tradução de Manuel Odorico Mendes. Campinas: UNICAMP/ Fapesp, 2008.

WILKINSON, Lancelot Patrick. The "Georgics" of Virgil: a critical survey. Norman: Oklahoma University Press, 1997.

WILLIAMS, Gordon. The blending of Greek and Roman. In: WILLIAMS, Gordon. Tradition and originality in Roman poetry. Oxford: Clarendon Press, 1985, p. 250-357. 
